UDC 616.94-053.31-07-085.33(048.8)

DOI: $10.15587 / 2519-4798.2020 .209137$

\title{
MODERN APPROACHES TO DIAGNOSIS AND TREATMENT OF EARLY-ONSET NEONATAL SEPSIS
}

\section{T. Klymenko, O. Tsodikova, T. Serdceva}

Ранній неонатальний сепсис (РНС) залишається провідною причиною захворюваності та смертності, особливо серед дітей, щзо були народжені передчасно. Тому точна діагностика, оперативний моніторинг перебігу захворювання та ефективна терапевтична стратегія є гарантом підвищення якості надання медичної допомоги новонародженим, а також важливим резервом зниження перинатальних втрат.

Мета роботи - узагальнити сучасні погляди на діагностику та лікування раннього неонатального сепсису у новонароджених дітей з перинатальною патологією.

Результати досліджень та їх обговорення. Здійснено аналітичний огляд сучасних літературних даних щзодо проблемних питань діагностики РНС. Викладені підходи і сформульовані основні напрямки менеджменту РНС на сучасному етапі. Виявлено, щзо відсутність консенсусного визначення неонатального сепсису та неспецифічність клінічних даних є лімітуючим фактором своєчасної точної ідентифікації септичного процесу. Недостатня діагностична цінність існуючих лабораторних тестів призводить до дефектів реєстру і моніторингу даного захворювання, неможливості проведення однозначної оцінки існуючої епідеміологічної та мікробіологічної ситуачії в різних системах охорони здоров'я та подальшої ефективної реалізачії профілактичних заходів.

Висновки. В умовах сучасних наукових реалій жоден з існуючих лабораторних тестів не може достатньо надійно підтвердити або спростувати наявність РНС у новонародженої дитини, щяо детермінує пошук нових перспективних лабораторних тестів з високим діагностичним та прогностичним потенціалом. Оптимальною лікувальною тактикою новонароджених з РНС є застосування антибіотиків широкого спектру діi

Ключові слова: новонародженні, неонатальний сепсис, ранній неонатальний сепсис, діагностика, антибактеріальна терапія. Однак сьогодні глобальна проблема надмірного нераціонального призначення антибактеріальних препаратів асоиіюеться з формуванням мультирезістнетних штамів бактерій, а також розвитком віддалених несприятливих наслідків, щуо вимагає вдосконалення діагностичних $і$ лікувальних алгоритмів ведення дітей з групи ризику по розвитку НС шляхом впровадження комплексного підходу $з$ використанням сучасних точних тестів в динаміці захворювання

Copyright (C) 2020, T. Klymenko, O. Tsodikova, T. Serdceva.

This is an open access article under the CC BY license (http://creativecommons.org/licenses/by/4.0).

\section{Introduction}

The problem of early diagnosis and effective management of neonatal sepsis (NS) is a leading area of modern perinatology around the world $[1,2]$. This is due to the severity of clinical manifestations, the development of multiple organ failure and adverse long-term consequences of the disease, as well as the high mortality rate of this pathology, especially among premature infants [3, 4]. World statistics show a significant geographical heterogeneity in the incidence of NS. The incidence of sepsis in developed countries is $0.28-0.77$ per 1000 children born $[5,6]$. According to the Center for Medical Statistics of the Ministry of Health of Ukraine, the frequency of NS is 0.69 per 1,000 live births. Despite the low official figures, the true incidence of NS is likely to be significantly higher. Accurate diagnosis and timely effective therapeutic strategy of NS is a reserve for reducing perinatal losses, as well as indicators of child disability and mortality [7-9].

The aim of the work is to generalize modern views on the diagnosis and treatment of early neonatal sepsis in newborns with perinatal pathology.
2. The issue of terminology and classification of neonatal sepsis

The history of the study of pathophysiological foundations and terminological interpretation of the concept of "sepsis" lasts for thousands of years - a disease known since ancient civilization [10]. For a long time, perceptions of the development of sepsis were associated exclusively with infectious factors. However, at the beginning of the XX century, scientists emphasized the importance of studying the response of a macroorganism to an infectious agent, which determined the shift of the vector of sepsisology in the direction of the immunological concept of the disease [11]. According to modern notions, sepsis is defined as a life-threatening condition accompanied by organ dysfunction and caused by a pathological violation of the regulation of the immune response to infectious pathology [12]. At the same time, it should be emphasized that consensus on the definition of NS has not been reached to date, which leads to a certain subjectivity in the approach to verification of this pathology and leads to significant diagnostic defects and 
misconceptions about the true epidemiological situation in the country and the world [13].

Depending on the time of manifestation of clinical manifestations, it is accepted to distinguish between early-onset neonatal sepsis (EOS) and late neonatal sepsis. EOS develops in the first 72 hours of life and is usually the result of intrauterine infection by transplacental or ascending [14]. The global microbial landscape of sepsis in EOS is represented by Streptococcus agalactiae, Escherichia coli, Enterococcus faecalis, Klebsiella pneumoniae pathogens $[15,16]$.

\section{Diagnosis of EOS at the present stage}

Despite the progress made in providing medical care to newborns in children with perinatal pathology, timely diagnosis of sepsis remains a difficult task, primarily due to the nonspecificity of clinical manifestations and asymptomatic early stages of the disease [17].

According to the recommendations of the National Institute for Health and Care Excellence (NICE, UK), the clinical indicators of probable early neonatal infection are [18]:

1. Discoloration of the skin (jaundice in the first 24 hours of life, central cyanosis).

2. Signs of violation of respiratory status (apnea, the need for prosthetic external respiratory function, respiratory distress syndrome, which manifested later than 4 hours after birth).

3. Signs of dysfunction of the cardiovascular system (cardiac arrhythmia, hypotension, signs of shock, the need for resuscitation, persistent pulmonary hypertension).

4. Deviant neurological symptoms (behavior change, muscle tone disorders, convulsive syndrome, clinical signs of neonatal encephalopathy).

5. Signs of dysfunction of the gastrointestinal tract (decreased tolerance to enteral feeding, vomiting, vomiting, bloating).

6. Violations of temperature hemostasis, not explained by environmental factors (thermometry data $<36^{\circ} \mathrm{C}$ or $>38^{\circ} \mathrm{C}$ ).

7. Hemostasiological disorders of unclear genesis (bleeding, thrombocytopenia, abnormalities of the coagulation system).

8. Metabolic disorders (hypo- or hyperglycemia, acidemia of metabolic genesis - BE - $10 \mathrm{mmol} / \mathrm{l}$ and above).

9. Oliguria within 24 hours.

10. Local signs of infection.

The localization of septicemic foci of infection can be different: respiratory organs, central nervous system, digestive and urogenital tracts, musculoskeletal system, skin. Given that the entrance gates of NS infection are usually the mucous membranes of the respiratory and digestive tracts, septic foci are most often presented by pneumonia and necrotic enterocolitis [17].

Bacteriological examination of blood, to date, remains the "gold standard" for the diagnosis of NS [19]. However, factors such as the intermittent nature of bacteremia, low density of microbial pathogens, violation of blood sampling techniques (insufficient laboratory mate- rial, blood sampling after antibacterial therapy), the appointment of maternal antibiotics during childbirth significantly limit the range of diagnostic significance of the study. In addition, the minimum time to obtain a blood culture result is 48 hours, which delays the verification of an accurate diagnosis and delays the appointment of effective NS therapy [20].

Interpretation of general blood counts is a standard and easy-to-perform diagnostic step in neonates with suspected NS. Changes in the general analysis of blood that may be evidence of probable infection [21]:

1. The number of leukocytes $<4.99$ or $>30 \times 109 / 1$ in the first 3-4 days of life of the newborn or $>20 \times 109 / 1$ starting from 4 days.

2. The value of the leukocyte index $(\mathrm{LI})>0.16-0.2$.

3 . The absolute number of immature neutrophils (ANIN) $>1.5 \times 109$ in $\mathrm{mm}^{3}$ is suspicious, and $>2.0 \times 109 / 1$ is evidence of a septic process. After 4 days of life ANIN $>1.0 \times 109 / 1$ may be of diagnostic value (depending on gestational age and life expectancy of the child).

4. The absolute number of neutrophils $(A N N)<1800$ in $\mathrm{mm}^{3}$ at birth and $<7800$ at the age of 12-14 hours of life is the most specific indicator.

Markers of systemic inflammatory response C-reactive protein (CRP) and procalcitonin (PCT) play a significant role in the diagnosis and prediction of the course of NS.

To date, it has been proven that only the quantitative determination of CRP in blood serum is informative, with an increased value of more than $10 \mathrm{mg} / \mathrm{l}$. It is important to note that, according to a number of studies, the existing dependence of serum CRP levels on gestational age and body weight limits the diagnostic value of the test and emphasizes the need to develop and implement specific nomograms based on these criteria. Modern scientific work emphasizes that CRP is not a correct diagnostic marker in the diagnosis of sepsis in infants with extremely low birth weight (ELBW) due to insufficient liver reactivity in preterm infants in contrast to more mature premature and full-term newborns [22]. Determining factors of the elevated level of this marker may be such pathological conditions of the perinatal period as asphyxia at birth and meconium aspiration syndrome [23, 24].

The diagnostic properties of PCT are limited by the physiological increase in its level in the first 4872 hours of life, which does not allow to recommend it as a criterion for diagnosing EOS, while the long half-life of this marker complicates operational monitoring of the disease [25].

Thus, the above indicates the need to expand the biomarker panel for the diagnosis of NS in order to improve the system of medical care for newborns with perinatal pathology of different gestational ages. The latest scientific research demonstrates the high diagnostic and prognostic potential of new promising laboratory tests of the systemic inflammatory response - presepsin and trigger receptor of myeloid cells of the first type (TREM-1) [26, 27]. 


\section{Basic principles and directions of antibacterial therapy of EOS}

Clinical suspicion of EOS is an indication for immediate administration of antibacterial therapy (ABT) [21]. In this case, failure to perform the required amount of examination should not affect the timeliness of the clinical decision on the scope and nature of the treatment strategy. Given the limited time resources to clarify the etiological factor and sensitivity of the selected infectious agent, the use of deescalation type of therapy is justified. The algorithm of the initial empirical scheme of ABT includes the prescription of semi-synthetic aminopenicillin in combination with an aminoglycoside.

At emergence of clinical signs of disturbance of the general condition of the child (decrease in volume of motor activity, suppression of physiological reflexes, change of behavior, disturbance of a muscular tone, decrease in tolerance to enteral food, change of color of integuments) treatment of the child should be carried out in intensive care units with continuous monitoring of vital signs.

36 hours after the start of the initial ABT, it is necessary to conduct a thorough assessment of the child's condition, analyze the data of additional laboratory tests and anticipate the need to change antibacterial drugs. If the child's condition is satisfactory, there are no clinical indicators of infection and a dynamic increase in CRP levels, as well as a negative result of bacteriological blood culture - empirical ABT should be stopped. If the gram-negative etiology of sepsis is confirmed, the thera- py is intensified by the appointment of cefotaxime. It should be noted that ceftriaxone is not prescribed to premature babies and newborns with jaundice.

The duration of ABT of EOS in the absence of complications is $7-10$ days. In the absence of positive dynamics in the child's condition and/or the manifestation of meningitis, enterocolitis, it is recommended to consider continuation of ABT [28].

\section{Conclusions}

Thus, the analysis of modern scientific data showed that in modern scientific realities none of the existing laboratory tests can reliably confirm or deny the presence of EOS in the newborn, which determines the search for new promising laboratory tests with high diagnostic and prognostic potential. The optimal treatment tactic for newborns with EOS is the use of broad-spectrum antibiotics. However, today the global problem of excessive irrational prescribing of antibacterial drugs is associated with the formation of multidrug-resistant strains of bacteria, as well as the development of longterm adverse effects, which requires improved diagnostic and treatment algorithms for children who are in the risk group of the development of neonatal sepsis by implementing a comprehensive approach using modern accurate tests in the dynamics of the disease.

\section{Conflict of interest}

The authors declare that they have no conflicts of interest.

\section{References}

1. Benitz, W. E., Achten, N. B. (2020). Finding a role for the neonatal early-onset sepsis risk calculator. EClinicalMedicine, 19, 100255. doi: http://doi.org/10.1016/j.eclinm.2019.100255

2. Puopolo, K. M. (2019). Neonatal sepsis evaluation across the pond. Archives of Disease in Childhood - Fetal and Neonatal Edition, 105 (2), 116-117. doi: http://doi.org/10.1136/archdischild-2019-317840

3. Puopolo, K. M., Benitz, W. E., Zaoutis, T. E. (2018). Management of Neonates Born at $\leq 34$ 6/7 Weeks' Gestation With Suspected or Proven Early-Onset Bacterial Sepsis. Pediatrics, 142 (6), e20182896. doi: http://doi.org/10.1542/peds.2018-2896

4. Wattal, C., Kler, N., Oberoi, J. K., Fursule, A., Kumar, A., Thakur, A. (2019). Neonatal Sepsis: Mortality and Morbidity in Neonatal Sepsis due to Multidrug-Resistant (MDR) Organisms: Part 1. The Indian Journal of Pediatrics, 87 (2), 117-121. doi: http:// doi.org/10.1007/s12098-019-03106-Z

5. Giannoni, E., Agyeman, P. K. A., Stocker, M., Posfay-Barbe, K. M., Heininger, U., Spycher, B. D. et. al. (2018). Neonatal Sepsis of Early Onset, and Hospital-Acquired and Community-Acquired Late Onset: A Prospective Population-Based Cohort Study. The Journal of Pediatrics, 201, 106-114.e4. doi: http://doi.org/10.1016/j.jpeds.2018.05.048

6. Schrag, S. J., Farley, M. M., Petit, S., Reingold, A., Weston, E. J., Pondo, T. et. al. (2016). Epidemiology of Invasive Early-Onset Neonatal Sepsis, 2005 to 2014. Pediatrics, 138 (6), e20162013. doi: http://doi.org/10.1542/peds.2016-2013

7. Heorhiiants, M. A., Zhovnir, V. A., Korsunov, V. A., Dmytriiev, D. V., Posternak, H. I., Snisar, V. I., Shchurovska, I. P. (2017). Unified clinical protocol of emergency, primary, secondary (specialized) and tertiary (highly specialized) medical care and intensive care Septic shock in children (project) (part 2). Pain, Anesthesia and Intensive Care, 4 (81), 11-26. doi: http://doi.org/10.25284/2519-2078.4(81).2017.119236

8. Wagstaff, J. S., Durrant, R. J., Newman, M. G., Eason, R., Ward, R. M., Sherwin, C. M. T., Enioutina, E. Y. (2019). Antibiotic Treatment of Suspected and Confirmed Neonatal Sepsis Within 28 Days of Birth: A Retrospective Analysis. Frontiers in Pharmacology, 10. doi: http://doi.org/10.3389/fphar.2019.01191

9. Zea-Vera, A., Ochoa, T. J. (2015). Challenges in the diagnosis and management of neonatal sepsis. Journal of Tropical Pediatrics, 61 (1), 1-13. doi: http://doi.org/10.1093/tropej/fmu079

10. Nikonov, V. V., Sokolov, A. S., Feskov, A. E. (2017). Sepsis from antiquity to contemporaneity. A view through the centuries. Emergency Medicine, 3 (82), 73-81. doi: http://doi.org/10.22141/2224-0586.3.82.2017.102327

11. Reinhart, K., Bauer, M., Riedemann, N. C., Hartog, C. S. (2012). New Approaches to Sepsis: Molecular Diagnostics and Biomarkers. Clinical Microbiology Reviews, 25 (4), 609-634. doi: http://doi.org/10.1128/cmr.00016-12

12. Singer, M., Deutschman, C. S., Seymour, C. W., Shankar-Hari, M., Annane, D., Bauer, M. et. al. (2016). The Third International Consensus Definitions for Sepsis and Septic Shock (Sepsis-3). JAMA, 315 (8), 801-810. doi: http://doi.org/10.1001/jama.2016.0287 
13. Wynn, J. L. (2016). Defining neonatal sepsis. Current Opinion in Pediatrics, 28 (2), 135-140. doi: http://doi.org/10.1097/ mop.0000000000000315

14. Polin, R. A. (2012). Management of Neonates With Suspected or Proven Early-Onset Bacterial Sepsis. Pediatrics, 129 (5), 1006-1015. doi: http://doi.org/10.1542/peds.2012-0541

15. Johansson Gudjónsdóttir, M., Elfvin, A., Hentz, E., Adlerberth, I., Tessin, I., Trollfors, B. (2019). Changes in incidence and etiology of early-onset neonatal infections 1997-2017 - a retrospective cohort study in western Sweden. BMC Pediatrics, 19 (1). doi: http://doi.org/10.1186/s12887-019-1866-Z

16. Shehab El-Din, E. M. R., El-Sokkary, M. M. A., Bassiouny, M. R., Hassan, R. (2015). Epidemiology of Neonatal Sepsis and Implicated Pathogens: A Study from Egypt. BioMed Research International, 2015, 1-11. doi: http://doi.org/10.1155/2015/509484

17. Shah, B. A., Padbury, J. F. (2014). Neonatal sepsis: an old problem with new insights. Virulence, 5 (1), 170-178. doi: http:// doi.org/10.4161/viru.26906

18. Neonatal infection (early onset): antibiotics for prevention and treatment (2012). Clinical guideline. Available at: https://www. nice.org.uk/guidance/cg149/resources/neonatal-infection-early-onset-antibiotics-for-prevention-and-treatment-pdf-35109579233221

19. Wynn, J. L., Wong, H. R., Shanley, T. P., Bizzarro, M. J., Saiman, L., Polin, R. A. (2014). Time for a Neonatal-Specific Consensus Definition for Sepsis. Pediatric Critical Care Medicine, 15 (6), 523-528. doi: http://doi.org/10.1097/pcc.0000000000000157

20. Klingenberg, C., Kornelisse, R. F., Buonocore, G., Maier, R. F., Stocker, M. (2018). Culture-Negative Early-Onset Neonatal Sepsis - At the Crossroad Between Efficient Sepsis Care and Antimicrobial Stewardship. Frontiers in Pediatrics, 6. doi: http:// doi.org/10.3389/fped.2018.00285

21. Kostiuk, O. O., Shunko, Ye. Ye., Krasnova, Yu.Yu. (2014). Rannii neonatalnyi sepsys. Osnovni napriamky diahnostyky ta likuvannia. Neonatolohiia, khirurhiia ta perynatalna medytsyna, 4 (3 (13)), 104-109.

22. Dritsakou, K., Liosis, G., Gioni, M., Glynou, E., Avdeliodi, K., Papagaroufalis, K. (2014). CRP levels in extremely low birth weight (ELBW) septic infants. The Journal of Maternal-Fetal \& Neonatal Medicine, 28 (2), 237-239. doi: http://doi.org/10.310 9/14767058.2014.908842

23. Hofer, N., Jank, K., Strenger, V., Pansy, J., Resch, B. (2015). Inflammatory indices in meconium aspiration syndrome. Pediatric Pulmonology, 51 (6), 601-606. doi: http://doi.org/10.1002/ppul.23349

24. Muniraman, H., Gardner, D., Skinner, J., Paweletz, A., Vayalakkad, A., Chee, Y. H. et. al. (2017). Biomarkers of hepatic injury and function in neonatal hypoxic ischemic encephalopathy and with therapeutic hypothermia. European Journal of Pediatrics, 176 (10), 1295-1303. doi: http://doi.org/10.1007/s00431-017-2956-2

25. Lee, J., Bang, Y. H., Lee, E. H., Choi, B. M., Hong, Y. S. (2017). The influencing factors on procalcitonin values in newborns with noninfectious conditions during the first week of life. Korean Journal of Pediatrics, 60 (1), 10-16. doi: http:// doi.org/10.3345/kjp.2017.60.1.10

26. Bellos, I., Fitrou, G., Daskalakis, G., Thomakos, N., Papantoniou, N., Pergialiotis, V. (2018). Soluble TREM-1 as a predictive factor of neonatal sepsis: a meta-analysis. Inflammation Research, 67 (7), 571-578. doi: http://doi.org/10.1007/s00011-018-1149-4

27. Parri, N., Trippella, G., Lisi, C., De Martino, M., Galli, L., Chiappini, E. (2019). Accuracy of presepsin in neonatal sepsis: systematic review and meta-analysis. Expert Review of Anti-Infective Therapy, 17 (4), 223-232. doi: http://doi.org/10.1080/1478721 0.2019 .1584037

28. Shunko, Ye. Ye. (Ed.) (2014). Neonatolohiia: natsionalnyi pidruchnyk. Vol. 1. Kyiv, 960.

Received date 26.05.2020

Accepted date 22.06.2020

Published date 31.07.2020

Tetiana Klymenko, MD, Professor, Head of Department, Department of Neonatology, Kharkiv Medical Academy of Postgraduate Education, Amosova str., 58, Kharkiv, Ukraine, 61176

E-mail: klimenko57.t@gmail.com

Olha Tsodikova, MD, Professor, Head of Department, Department of Outpatient Pediatrics, Kharkiv Medical Academy of Postgraduate Education, Amosova str., 58, Kharkiv, Ukraine, 61176

E-mail: polipedaitr@med.edu.ua

Elena Serdceva, PhD, Associate Professor, Department of Sciences in Medicine, Neonatology, Kharkiv Medical Academy of Postgraduate Education, Amosova str., 58, Kharkiv, Ukraine, 61176

E-mail: serdceva.ea59@gmail.com 